\title{
Guaranteeism in Administrative Acts
}

\author{
Enrique Rabell-Garcia \\ Ph. D. in Public Affairs, Indiana University. Faculty of Law, Universidad Autónoma de Querétaro, México. E-mail: \\ erabell@mail.com
}

Received: September 11, 2018

Accepted: October 9, 2018 Online Published: October 25, 2018

doi:10.11114/ijlpa.v1i2.3716

URL: https://doi.org/10.11114/ijlpa.v1i2.3716

\begin{abstract}
Under the reform of article 1 of the Federal Constitution (June 10, 2011), all government authorities have the obligation to respect human rights. The main inquiry of this essay is whether the Executive can, ex officio, revoke administrative acts for violations of human rights or stop enforcing a law it deems unconstitutional. Following this line of inquiry, for the purposes of this essay, the hypothesis is affirmative. The first part of this work analyzes several techniques and their comprehensive interpretation. Doctrine and comparative law are used to frame the issue. The second part consists of a constitutional analysis of article one under several legal interpretation theories to obtain preliminary results. The third part focuses particularly on revocation in the Administrative Procedure Act and the Mexican Federal Tax Code, in addition to relevant case law. Lastly, it is concluded that, in certain cases involving legal certainty, revocation can apply; however, refusal to enforce a law deemed unconstitutional cannot.
\end{abstract}

Keywords: Constitutional Law, Public Administration, Human Rights, Administrative Acts.

\section{Introduction}

The theory of separation of powers, and its checks and balances, is now particularly relevant with the reform of article 1 of the Constitution, which enshrines the protection of human rights. In particular, the reform of article 1 of the Political Constitution of the United Mexican States, which entered into force on June 10, 2011 with a marked orientation toward natural law, acknowledges the government authorities' duty to enforce and preserve human rights. Much has been said about its effects over the Judicial Branch. However, little has been studied with respect to the Executive Branch or its administrative acts. Paragraph three of the article in question states that:

"All authorities, within the scope of their powers, have the duty to promote, respect, protect, and ensure human rights in accordance with the principles of universality, interdependence, indivisibility, and progressive realization. Consequently, the State must prevent, investigate, sanction, and repair human rights violations, under the terms established by law."

Thus, the Executive also has an obligation to respect human rights. This is plainly clear when it comes to the Executive's public safety and law enforcement obligations. However, the main inquiry is whether the Executive has the power to either revoke administrative acts ex officio on the grounds that they infringe human rights or whether it could stop enforcing a law as unconstitutional. This question raises both an academic as well as a practical dilemma. On the one hand, the Executive can only enforce or administer the law strictly, and any disputes arising there from are submitted to the courts or to legislative reform. According to Brewer-Carias (1969), because they create subjective rights, administrative acts affecting only the interested party, once final (i.e. once they can no longer be legally challenged), constitute administrative "res judicata" and cannot be "revoked" by the authorities. On the other hand, if the Executive can amend or revoke their act, which has the advantage of expediting solutions to the public's problems, it can also use that power to its own advantage to perform acts outside the law.

Procedures for revoking and annulling administrative acts are already regulated, albeit irregularly, in several laws, such as the Administrative Procedure Act ("Ley del Procedimiento Administrativo") and the Mexican Federal Tax Code ("Código Fiscal de la Federación"). The purpose of this study is to determine whether, under that reform, the Executive could modify, change, amend, or annul its own ex officio acts, with all the implications that this entails. Second, this could deeply disturb and modify the classic separation of powers, despite the power of veto during the lawmaking process and procedures for challenging the constitutionality of a law. This raises a third question as to whether the Executive could repeal a law in full or in part, by revoking its chapters or sections. 
Following this line of inquiry, for the purposes of this essay, the hypothesis is affirmative. Hermeneutic and comprehensive analysis will be applied as principal method to solve the hypothesis. The specific techniques within the analysis are the historical, grammatical, systematic, legal-sociological, and general principles of law. The results from each technique will be confronted as mentioned to arrive at the final conclusions.

Thus, in the second part, this essay analyzes basic theoretical questions and comparative law. The third part presents comparative law to show different countries solutions to the stated problem. The next two parts assess the constitutionality of article 1 using the following interpretation techniques: historical, grammatical, systematic, legal-sociological, and general principles of law. Part six focuses particularly on revocation procedures in the Administrative Procedure Act and the Mexican Federal Tax Code; while analyzing relevant case law in part seven. The final part describes the consequences of the reform and draws conclusions on the matter.

\section{Theoretical Framework}

In both Spanish and English, the term "revocar" or "revoke" derives from the Latin word revocatio, which means to rescind or call back. The Spanish Royal Academy (2014) defines "revocar" ("revoke") as "invalidating, substituting or amending an order or decision by any authority other than the issuer" and "revocación" ("revocation") as "a legal act that repeals a prior legal act by choice of the issuer." Garcia de Enterria and Fernandez $(1993,623)$ define the term as follows: "revocation is a definitive repeal by the Administration of one of its previous acts by issuing a new act to the contrary." In addition, they sustain that this seemingly simple concept has presented a multitude of difficulties, from its historical origins, dominated by conventionalism and misconceptions, to its innate technical complexity.

From a doctrinal point of view, there is much controversy surrounding the scope of revocations, particularly with respect to their similarity to annulments. Thus, for example, according to Agustin Gordillo $(2012,3)$, when acts are extinguished for reason of unlawfulness, whether in administrative proceedings (revocation) or court proceedings (annulment), the consequences of that extinguishment depend solely on the defect of the challenged act. If the act's defect is not too grievous, it can be subject to annulment, which will have the same effects (e.g. non-retroactive extinguishment), regardless of whether the act was annulled or revoked on the grounds of unlawfulness. However, if the act's defect is grievous, the act is void; and its annulment as well as its revocation on the grounds of unlawfulness are governed by the same principles, while its extinguishment is retroactive. In that vein, revocation faithfully mirrors the doctrine of validity and effectiveness of legal acts and applies it to administrative acts. He then concludes that the consequences of that extinguishment do not depend on whether the act was "revoked" or "annulled," but rather on the defect that rendered the act extinguishable.

According to Fernandez Sagardi $(2000,7)$, the basic difference is that administrative remedies are decided by the authority that issued the challenged decision, i.e. there is no third-party ruling on the matter, while annulments are decided by a third party, i.e. the "courts." In each case, there are different theoretical principles at play. In the case of administrative remedies, the guiding principle is that of self-preservation, while in court cases, it is that of procedural equality. In addition, Margain Manautou $(2007,159)$ adds another difference: the former originates in the context of administrative disputes, while the latter does so in the context of a trial. The former seeks to shed light on the law for administrative purposes, the latter for jurisdictional purposes. Lastly, the former results in an administrative ruling and the latter in a judgment.

Current administrative codes reproduce the doctrine of the elements of administrative acts and their grounds for annulment, relative nullity, or absolute nullity, in addition to also governing revocation, which makes it difficult to differentiate between these concepts both in theory and in practice. For now, it should remain the initial notion that there is revocation when the executive authority, either ex officio or upon request of the interested party, revokes an administrative act, and there is annulment when a special administrative or judicial proceeding is required to declare such invalidity or nullity.

\section{Comparative law}

\subsection{Spain}

In the case of Spain, Lavilla $(1961,63)$ sustains that the foundations of ex officio review of administrative acts are the following:

“a) objective reasons of unlawfulness or untimeliness, or b) subjective reasons, relating to an infringement of interests or subjective rights. Article 115 of the Administrative Procedure Act and article 41 of the Law Regulating the Administrative Jurisdiction (Ley reguladora de la Jurisdicción contencioso-administrativa) allow for objective review if the legal system is breached, which, in turn, is an explicit requirement for ex officio administrative reviews under articles 109 and 110 of the Administrative Procedure Act."

In addition, the Opinion issued by the State Council on November 7, 1968 established that, for revocation to be 
applicable, there must be a clear and serious breach of the law.

Article 105(1) of the Administrative Procedure Act (APA) is the fundamental rule for defining revocation and any potential ex officio annulment of an administrative act (Santamaria 2000, 441-442). To this end, the following phrasing was enacted in one of the latest reforms: "Public Administrations could, at any time, revoke their grave or unfavorable acts, provided that said revocation does not constitute an unlawful waiver or exemption, or otherwise infringe the equality principle, or affect the public interest or legal system."

The new phrasing emphasizes that revocation requires that acts be unfavorable, infringe the equality principle, or affect the public interest or legal system. Therefore, revocation must be provided for by law. González Pérez (2003, 360-362) argues that "unfavorable acts are those whose elimination results in benefits, utility, or gain, i.e. the purpose of their elimination is to prevent harm or inconvenience." In "triangular" proceedings (i.e. proceedings involving civilians with opposing positions) where the act in question may be favorable to one party but unfavorable to the other, the State

Council held in Opinion No. 2082/1995 that revocation is not applicable. The author further argues that limitations to the revocation of administrative acts include vested rights, unlawful waivers or exemptions, infringing the legality principle, and affecting the public interest.

With respect to article 105(1) of Spanish Law No. 30/92 on General Government and the Common Administrative Procedure (Ley Española 30/92 de Régimen Jurídico de las Administraciones Públicas y del Procedimiento Administrativo Común) and article 61 of its Chilean counterpart, in his research on revocation, Fortes Martin (2006, 149-153) concluded that:

"the relevant consequences of the revocation of an administrative act, especially in light of its repercussions on the legal certainty of the act's recipient, demand that the revocation process be conducted in strict compliance with a series of requirements. That is why the Public Administration cannot exercise this power without a prior norm enabling it to do so and exhaustively determining the cases in which it may proceed."

Lastly, article 219 of General Tax Act No. 58/2003 (Ley General Tributaria), establishes the following requirements for the revocation of acts enforcing taxes or imposing sanctions: that the law be clearly violated, or a particular legal situation reveal the inapplicability of the act, or the interested parties have been rendered defenseless in the proceedings; the limitation period must not have expired; it must be declared ex officio and only by the body authorized to do so by regulation, which must be different from the act's issuing body; and the maximum notice period is six months. Therefore, in Spain, revocation can only apply when it is provided for in a secondary norm and the requirements or elements affecting the administrative act are duly established.

\subsection{Colombia}

In Colombia, the Administrative Code of 1984 (Código Contencioso Administrativo de 1984) explicitly provided for ex officio revocation of administrative acts. In this respect, article 69 (reiterated in article 93 of the new Code) currently stipulated that:

"Administrative acts must be revoked, ex officio or at the request of the interested party, by the same officials who issued them or by their direct superiors, in each of the following cases:

1. When they clearly infringe the Political Constitution or the Law.

2. When they are contrary to, or violate, the public or social interest.

3. When they result in an unjustified harm to a person."

In addition to that article, the Constitutional Court of Colombia has defined the term "revocation" as follows:

"Direct revocation of administrative acts-Specific grounds for revocation of disciplinary actions-Threat or breach to fundamental rights as grounds for revocation. Direct revocation of administrative acts only applies on the following grounds: (i) manifest unconstitutionality or unlawfulness; (ii) infringement of the public or social interest; (iii) unjustified harm to a person."

This exceptionality is reinforced in the specific case of disciplinary investigations, which require a manifest breach or threat to fundamental rights. In both cases, the grounds or situations in which revocation is applicable have been established. Thus, because Colombian administrative authorities can revoke, ex officio or at the request of the interested party, any administrative act that infringes the Constitution, they have broad and diffuse powers of constitutional control.

In addition, the Constitutional Court (2015) broadened the concept of direct revocation of administrative acts when it ruled that:

"as a constituent act, it is a decision that invalidates a prior act, which may operate ex officio or at the request of 
the interested party, and, ultimately, with new consequences for the future. In the first case, the act is revoked by the official who issued it or by his or her direct superior. In the second case, the act is revoked by the competent official at the request of the interested party."

That act is subject to the previously mentioned requirements.

\subsection{Costa Rica}

Another interesting case is that of Costa Rica's new General Law of Public Administration (Ley General de Administración Pública, LGAP), which authorizes the Executive to annul certain administrative acts ex officio. According to Saborio Valverde $(2002,143)$ :

"As per article 174(2) LGAP, ex officio annulment of a relatively null act is discretionary and must be justified under specific and current grounds. In these cases, annulment is only applicable if the annulled act does not declare rights to a third party; otherwise, administrative annulment is not allowed and the Administration must resort to the detriment proceedings established in articles 10 and 35 of the Law Regulating the Administrative Jurisdiction (Ley de la Jurisdicción Contencioso-Administrativa, LRJCA) (183(3) LGAP). The Administration's discretionary power extends to those cases in which administrative remedies and claims have expired, provided that review is conducted in the interested party's favor with observance of his or her rights (183(1) LGAP)."

In this case, the term "annulment" was used instead of "revocation." However, both terms have the same effect under the law in question. The case of Venezuela and several other Latin American countries is similar (Brewer-Carias 2003, 246-251).

\section{Precedents of Article 1 of the Constitution}

The direct precedent of today's article 1 was article 1 of the 1857 Constitution, which used to read:

"Article 1. The people of Mexico acknowledge that the rights of man constitute the foundation and purpose of social institutions. Thus, we hereby declare: that all laws and authorities in the country must respect and uphold the guarantees set forth in this Constitution."

The influence of natural law is evident in the use of the term "rights of man" and the obligation of "all [...] authorities" to ensure the guarantees conferred by Law. The strong influence of positivism toward the late nineteenth century triggered this text's amendment. Thus, the text enacted in 1917 was the following:

"Article 1. In the United Mexican States, every individual shall enjoy the guarantees provided by this Constitution, which cannot be restricted or suspended, except under the conditions set forth in the Constitution itself."

The influence of positivism is clear in the addition of the concept of "provided" by the Constitution. Similarly, "all [...] authorities" was also omitted.

The current article has been subject to few reforms: August 14, 2001, prohibiting all forms of discrimination; December 4, 2006, replacing the term "disabilities" with "different abilities" to use broader human rights language; and lastly, the 2011 reform, which once again incorporated natural law.

Although the current Constitution has no direct precedents with respect to the Executive's obligation to ensure human rights, that obligation already existed since the Constitution's enactment, under articles 14 and 16, which guarantee hearings and due process. However, according to the separation of powers doctrine, based on several articles of the Constitution (mainly 49 and 89), the Executive was historically not allowed to revoke a final and unlawful administrative act or to interpret or stop enforcing a law, even if it was notoriously unconstitutional (because a law is an act of Congress).

\section{Constitutional Analysis}

\subsection{Grammatical Interpretation}

Grammatical study is based on the literal meaning of words. "Literal," according to the Dictionary of the Spanish Royal Academy (2014) means "adhering to fact or to the ordinary construction or primary meaning of a term or expression." In that sense, although article 1, paragraph 3, of the Constitution, highlights "the obligation to promote, respect, protect and guarantee human rights [...]," it does not specifically highlight the power to interpret and repeal a law or revoke administrative acts.

However, the final part of that paragraph reads: "el Estado deberá prevenir, investigar, sancionar y reparar las violaciones a los derechos humanos, en los términos que establezca la ley" ["the state must prevent, investigate, sanction, and repair human rights violations, under the terms established by law"]. For purposes of this essay, the Spanish word "reparar" ["repair"] as used in the Mexican Constitution, originally in Spanish, offers a solution. 
According to the Dictionary of the Spanish Royal Academy (2014), "reparar" ["repair"] means:

"1. Amend, correct, or remedy.

2. Relieve or satisfy the offended party.

3. Remedy or prevent damage or harm.

4. Pay attention to, consider, or reflect upon."

In that sense, the Executive can repair, i.e. correct or remedy a damage or harm when particular human rights are affected, which means authorizing its revocation of administrative acts. However, that provision is not absolute, as paragraph three itself establishes (in line with the guarantee of legal certainty) that the revocation must comply with terms of the law. Thus, revocation, and its procedure, must be explicitly authorized and outlined by statute.

This literal interpretation of the text as written originally in Spanish could also result in the Executive repealing a law (that it deemed unconstitutional) if the factual circumstances at hand should happen to fall within a law that authorized it to do so under a literal interpretation of the word "prevent," as used in the paragraph cited above, coupled with the previously described interpretation of "repair" as "amend, correct, or remedy."

\subsection{Teleological or Systematic Interpretation}

According to Víctor Anchondo (2013), the article should be interpreted in harmony with the entire text of the law. In the present case, this could be applied in two ways. First, it could be applied consistently with constitutional provisions that deal with the separation of powers. In classical doctrine, this leads to the conclusion that the Executive is limited only to enforcing the law, i.e. without interpreting, ceasing to enforce, or revoking administrative acts. In the opposite vein, new theories clearly demonstrate that the theory of strict separation of powers has been surpassed.

Second, the latest constitutional reforms have been assessed in order to determine whether the separation of powers doctrine is still in force, and, if so, what the scope or extent of the incorporation of human rights in the Constitution is. In this vein, the following precedents were found:

a. The reform of article 1 shifts from a positivist view (granting guarantees) to a natural law view (acknowledging human rights).

b. Article three stipulates that one of the purposes of the education provided by the Mexican State must be the promotion of human rights.

c. Asylum is granted to all political refugees and the right of refuge is recognized as a humanitarian right.

d. Article 18 underscores respect for human rights as the foundation of the penitentiary system.

e. Under the American Convention on Human Rights, article 33 of the Constitution was modified to eliminate the discretionary power of the Executive to deport foreigners.

f. Article 89(10) of the Constitution includes the obligation to incorporate "respect, protection, and promotion of human rights" into Mexico's foreign policy.

g. Public servants who fail to implement the recommendations of human rights committees are obligated to justify that refusal, and to make it public.

As revealed by these reforms, the Constitution reformer's intention was not only to incorporate the natural law human rights doctrine, but also (through different provisions) to empower the Executive to enforce it in many important acts. Extrapolating this interpretation of article 1, the Executive could review and revoke administrative acts ex officio and interpret or refuse to enforce a law if they infringed fundamental human rights.

\subsection{Legal-Sociological Interpretation}

Karl Lowenstein's legal-sociological method (1976, 216-219) takes into account real elements of power in the law, understood in its classic functions of creation and enforcement of the law and dispute resolution. Real elements of power are various factors that come into play in the social dynamics of a community, which entail economic, political, anthropological, social, and cultural considerations.

In the case at hand, i.e. when the Executive decides to revoke an administrative act or not to enforce a law, several social groups (associations, unions, political parties, companies, chambers of commerce, "ejidos" [Mexican communal lands used for agriculture], etc.) become deeply disturbed, regardless of whether the decision was discretionary and limited to a particular case or whether it affected the general public. In addition, although such measures could benefit an individual or group, its social consequence is that some groups or individuals would receive a privilege others did not, which affects equal treatment with respect to the specific administrative act in question.

As a result, under this interpretation, the Executive should not have the power to revoke or decide not to enforce a law on the basis of the social disturbances that could result from any such decision. A decision of this kind by the Executive 
could appear discretionary, benefitting some in detriment of others, and it could disrupt the relationship between the Executive and the people.

\subsection{General Principles of Law}

In this essay, it will be applied the general principles of law as a supplemental source of law. According to the Spanish philosopher Peces-Barba $(2005,70)$ :

"they are a source of fundamental rights, and they almost always supplement the lack of sources in this field, such as the Constitution and ordinary statutes. This is because the principles enshrined in substantive law (such as respect for human dignity or the principle of liberty) make way for, and foster the inclusion of, human rights when there are no specific norms to that effect."

From another point of view, Bidart Campos $(1989,60)$ argues that "the philosophy and ideology of human rights are the source of these principles, where these sources convert into a general principle the notion that human rights must be promoted, respected, and enforced."

Article 14(IV) of the Constitution states that, in civil court trials, judgments shall adhere to the letter or legal interpretation of the law, and in the absence thereof, to the general principles of law. However, the Constitution is silent with respect to administrative acts. While the use of general principles of law may be controversial for the purposes of this essay, this brief assessment is included as a supplement to the rest.

If, in this case, it takes into account that the way in which revocations are regulated may vary and the law is silent with respect to the power not to enforce a law, then based on the general principles of law (which include guaranteeism) and article 1 of the Constitution, our hypothesis is always affirmative with regard to the protection of human rights; i.e., in the face of a notoriously unlawful administrative act or unconstitutional law, the administrative authority is obligated to protect its subjects.

Following this logic, the only situation that could prove problematic with respect to these principles is that of "triangular" proceedings, in which a revocation could benefit one party in detriment of the other. This could force the Executive to weigh human rights against each other, which is usually the job or power of the Courts.

\section{Delegated Legislation}

\subsection{The Federal Administrative Procedure Act}

Article 3 of the Federal Administrative Procedure Act (Ley Federal de Procedimiento Administrativo) establishes the elements and requirements of administrative acts. With respect to omissions or irregularities, part 6 stipulates that "administrative acts can be annulled by the hierarchical superior of the issuer, except when the challenged act was issued by the head of a government body, in which case that body shall decide on the annulment." Article 7 contains the effects of an administrative act that is subject to annulment, which produces effects and is subject to remedy. In addition, article 8 stipulates that the administrative act is valid as long as it has not been declared invalid by an administrative authority or court. Article 11 lists, under title VI, as grounds for extinguishing an administrative act: "revocation, when required by the public interest, in accordance with the law." The law does not state that the authorities can revoke an act ex officio; although it can be inferred from article 6 that said act could be challenged.

However, article 83 stipulates that, once all administrative procedures have been exhausted, the interested party may file an appeal for review or resort to the courts. Similarly, according to article 85, the appeal is filed either before the hierarchical superior of the issuer of the administrative act or before the authority itself, when the issuer is the hierarchical superior. Article 91 states that, one of the effects of the appeal is that it can render the administrative act repealed, invalid, or subject to annulment (Title III) or amendment (Title IV).

Therefore, according to a systematic interpretation of the entire body of law in question, the Executive cannot revoke an administrative act ex officio, because the interested party must file for an appeal or submit the matter to the courts.

However, in the State of Queretaro, Mexico, the Administrative Procedure Act, which governs acts, proceedings, and resolutions issued by the public administration at a municipal level, does authorize ex officio revocation. Article 120 stipulates that the authorities can repeal a summons or sanction ex officio or at the request of the interested party when there is a manifest error or the individual can prove earlier compliance.

In light of the above, local secondary law stipulates that the only acts that can be revoked are summons or sanctions; however, they are not mandatory and must be limited to cases of manifest error or earlier compliance. The above highlights how relative the revocation of administrative acts really is. It is discretionary, but not in all cases. For example, when there are missing elements or procedural overreach, there must either be an unequivocal error or the summons must be rendered inapplicable due to prior compliance. 


\subsection{Mexican Federal Tax Code}

Article 36 stipulates that administrative rulings of an individual nature favoring a single person can only be modified by the Federal Court of Administrative Justice (Tribunal Federal de Justicia Fiscal y Administrativa) in a lawsuit initiated by the tax authorities. In addition, when the Ministry of Finance and Public Credit (Secretaría de Hacienda y Crédito Público) modifies general administrative rulings, effects occurring prior to the ruling will not be affected.

Tax authorities can review, at their discretion, administrative rulings by their hierarchical subordinates negatively affecting only the interested party, and if they are irrefutably proven to be in breach of tax provisions, said authorities can, only on that occasion, modify or revoke them in benefit of the taxpayer, provided that the taxpayer has not filed any claims against them or that the statute of limitations of those claims has not been reached and the fiscal credit has not reached maturity. Thus, ex officio revocation is applicable in these cases, even though the law does not specifically state that this power is ex officio.

Article 94 of the Tax Code specifically stipulates that rulings favoring civilians cannot be revoked or annulled by the administrative authorities; thus, they can only be challenged before the Federal Tax Court.

\section{Case law}

Case law has proven essential for filling gaps and loopholes in the law. Case law has clearly defined revocation and its applicability criteria. In particular, in volume 228, page 275, part 3 of the Appendix of the Federal Judicial Weekly ("Semanario Judicial de la Federación"), published in 1965, the Second Chamber of the Supreme Court stated that: "administrative authorities do not have the power to revoke rulings resolving a dispute when those rulings have created rights in favor of a third party or when they create rights in favor of the interested parties."

In that same volume, item one, page 277 states that "when the administrative act breaches the law, it cannot create rights, and it can be legally revoked." The above refers to administrative issues in general and can only apply when there is no specific legal provision to the contrary. However, this case law does not contemplate the possibility of ex officio revocation and dates back to before the constitutional reform.

\section{Conclusions}

In this essay, it was analyzed the human rights-related consequences of the constitutional reform affecting article 1 of the Constitution of Mexico. In particular, the relevant question mentioned whether the Executive could revoke an administrative act ex officio under the grounds that it manifestly violates human rights and/or whether it could cease to enforce a law it deems unconstitutional. The answer is affirmative; i.e. the Executive, at all three levels of government, has the power to revoke administrative acts or stop enforcing a law. It was shown that this power is not discretionary. Instead, in normative terms, revocation or non-enforcement must be duly authorized by law.

Revocation can apply ex officio or at the request of the interested party under several circumstances. In addition, it was differentiated cases in which revocation operates in favor or in detriment of a single individual from those in which the revocation in question benefits one party in detriment of another.

With regard to ex officio cases, if the original administrative act has already benefited an individual, based on the vested rights doctrine, Mazeaud (1962) sustains that the authorities cannot revoke the act ex officio, as that could infringe the human right to legal certainty. This view is held by several other authors as well. For example, Lares Martinez (1983, 216) adds that, once a right has been conferred, the administrative act becomes intangible, and therefore the administrative authority does not have the power to revoke it. The same applies to cases of administrative acts in light of which one party gained a right, while the other's rights were negatively affected ("triangular" case). Since one of the parties has a vested right, the situation is the same as in the first case. In these cases, for revocation or annulment to apply, there must be a specific administrative procedure law to that effect or administrative procedures must be followed. This situation was already provided for in the Tax Code, in which it is clear that when an act favors the interested party, the tax authority can only revoke or challenge it in court.

If the administrative act in question infringed human rights and affected only one individual, in light of the real elements of power at play and legal obligations of the authorities, ex officio revocation may apply under the following conditions:

a. It must be authorized by law.

b. The law must stipulate under what circumstances it applies (for example, when human rights enshrined in the federal or local Constitution and international treaties are manifestly infringed; when the public interest is negatively affected; in cases of force majeure; etc.).

According to Calvo Vergez (2008, 212-224), what makes revocation possible in fiscal matters are manifest legal breaches, i.e. acts that were issued on the basis of criteria that have been struck down by the courts; acts that are 
contrary to the interpretative criteria established by the administration; breaches of a community directive; acts issued to enforce a repealed law; and acts deemed invalid by the administration.

In that same vein, article 36 of the Federal Tax Code authorizes ex officio review by hierarchical superiors of the administrative acts of their subordinates when the administrative ruling affects only the interested party, is not favorable to the individual, and is unequivocally proven to be in breach of tax provisions. Therefore, ex officio revocation applies when stipulated by law and there is unequivocal proof that the tax authority's administrative act is in breach of tax laws.

If the individual requests revocation of an administrative act on the grounds that it is harmful to him or her, then all the previously described requirements must be met; thus, revocation in that case is comparable to an appeal under most laws. In the case of administrative acts where a third party acquired vested rights (i.e. "triangular"), revocation is applicable under a special or administrative procedure.

There are no direct precedents for the case of non-enforcement of a law. However, within the separation of powers or checks and balances doctrine, the following instruments operate in the Executive's favor: (1) the Executive's power to veto within legislative proceedings; (2) the Executive's power to challenge the constitutionality of an act or law as unlawful or in violation of the Constitution; ${ }^{2}$ (3) non-enforcement of the remedy for the protection of constitutional rights ("amparo"), which only affects the case at hand.

Once all these remedies are filed, no more remedies are available. Therefore, in that case, the answer is negative. Once vetoes and constitutionality challenges are exhausted, regardless of the results, the law in question becomes final and therefore constitutional, and the Executive does not have the power to reevaluate it. On the other hand, in accordance with legal certainty guarantees, a law that clearly, generically, and specifically establishes the cases in which the above applies is necessary, which seems to contradict the current legislative logic.

However, there is one more possibility both for ex officio revocation as well as for the non-applicability of a law or regulation: when there is a clear breach of human rights or when there is a court judgment to that effect. That is the case when the unconstitutionality judgments of the Mexican Supreme Court do not have general effects; when individuals are granted remedy for the protection of constitutional rights ("amparo"); or when there is a final judgment on the matter. In those cases, the effects of the judgment extend only to the parties in the dispute, and the question is whether its effects can be enforced at a general level; i.e. diffuse constitutional review from the perspective of guaranteeism and neo-constitutionalism. ${ }^{3}$

According to a systematic and teleological interpretation of the latest constitutional reforms, revocation should apply ex officio and any unconstitutional law should not be enforced. This is so especially because the Court has already found these administrative acts or this particular law to be in notorious violation of human rights. From a strictly positivist point of view, if the authority views the jurisprudence and judgments of the judicial branch as "law," then the answer is also affirmative.

\section{References}

Brewer-Carias, A. R. (1969). Las condiciones de recurribilidad del acto administrativo. Perspectivas del Derecho Público en la segunda mitad del siglo XX. Venezuela, Vol. V: 743-769.

Brewer-Carias, A. R. (2003). Principios del Procedimiento Administrativo en América Latina. Bogotá: Legis.

Calvo Vergez, J. (2008). En torno a los motivos que posibilitan la revocación de los actos tributarios, Zergak Gaceta Tributaria del País Vasco, 35, 205-246.

Campos, B., \& German, J. (1989). Teoría General de los Derechos Humanos. Mexico: UNAM.

Cancilleria. (1984). Código Contencioso Administrativo. Bogota: Colombia. Retrieved from https://www.cancilleria.gov.co/sites/default/files/Normograma/docs/codigo_contencioso_administrativo.htm (accessed October 20, 2015)

Corte Constitucional de la República de Colombia. (2015). Revocatoria directa - definición. Bogotá. http://www.corteconstitucional.gov.co/relatoria/2003/c-835-03.htm (accessed October 15, 2015).

Fernandez Sagardi, A. (2000). Comentarios y Anotaciones al Código Fiscal de la Federación. Mexico: Sicco.

Fortes Martin, A. (2006). Estudio sobre la Revocación de los Actos Administrativos. Revista de Derecho Valdivia, 19, 149-177.

Garcia de Enterria, E., \& Tomás Ramón Fernández. (1993). Curso de Derecho Administrativo I, 6a . ed. Madrid: Civitas.

Gonzalez Perez, J. (2003). La Ley Chilena de Procedimiento Administrativo. Revista de Administración Pública, 162, 359-389. 
Gordillo, A. (2012). El Acto Administrativo, Libro II, Reimpresión como Libro II del Tratado de Derecho Administrativo y Obras Selectas. Buenos Aires, t. V: FDA.

Instituto de Investigaciones Juridicas. (1917). Constitución Política de los Estados Unidos Mexicanos. Retrieved from http://info4.juridicas.unam.mx/ijure/fed/9/ (accessed November 10, 2014).

Instituto de Investigaciones Juridicas. (2014). Constitución Política de la República Mexicana de 1857. Retrieved from http://www.juridicas.unam.mx/infjur/leg/conshist/pdf/1857.pdf (accessed November 10, 2014).

Lares Martinez, E. (1983). Manual de Derecho Administrativo. Caracas: Universidad Central de Venezuela.

Lavilla Alsina, L. (1961). La Revisión de Oficio de los Actos Administrativos. Revista de Administración Pública, 34, 53-98.

Loewenstein, K. (1976). Teoría de la Constitución (2a. ed.). Barcelona: Ariel.

Margain Manautou, E. (2007). Introducción al Estudio del Derecho Tributario Mexicano (19a . ed.). Mexico: Porrua.

Mazeaud, Henri, et. al. (1962). Lecciones de Derecho Civil, Garantías. Vol. 1, Ediciones Juridica Europa-America.

Paredes, A., \& Emilio, V. (2013). Métodos de Interpretación Jurídica. Mexico: IIJ-UNAM. Retrieved from http://www.juridicas.unam.mx/publica/librev/rev/qdiuris/cont/16/cnt/cnt4.pdf (accessed November 4, 2015).

Peces-Barba, G., et. al. (2005). Lecciones de Derechos Fundamentales. Madrid: Dykinson.

Real Academia Española. (2014). "Literal," Diccionario de la Lengua Española. Madrid. Retrieved from http://lema.rae.es/drae/?val=literal (accessed October 18, 2014).

Real Academia Española. (2014). "Reparar," Diccionario de la Lengua Española. Madrid. Retrieved from http://lema.rae.es/drae/?val=reparar (accessed October 18, 2014).

Real Academia Española. (2014). "Revocación,” Diccionario de la Lengua Española. Madrid. Retrieved from http://dle.rae.es/?w=revocaci\%C3\%B3n\&m=form\&o=h (accessed October 18, 2014).

Saborio Valverde, R. (2002). Eficacia e Invalidez del acto administrativo (3 ${ }^{\mathrm{a}}$. ed.). San Jose, Costa Rica: Editorial Juricentro.

Santamaria Arinas, R. J. (2000). La Reforma del Artículo 105.1 LPC y la Revocación de los Actos Administrativos, Revista de Administración Pública, 151, 441-464.

\section{Copyrights}

Copyright for this article is retained by the author(s), with first publication rights granted to the journal.

This is an open-access article distributed under the terms and conditions of the Creative Commons Attribution License which permits unrestricted use, distribution, and reproduction in any medium, provided the original work is properly cited. 